\title{
Profile of Guided Discovery Learning Implementation Assisted by Virtual Lab and Students' Problem-Solving Skills on Gas Kinetic Theory
}

\author{
Abib Hani Mashurin ${ }^{1, a)}$, Husni Mubarok ${ }^{2, b)}$, Binar Kurnia Prahani ${ }^{1, \mathrm{c})}$ \\ ${ }^{1}$ Universitas Negeri Surabaya, Jl. Ketintang, Ketintang, Kec. Gayungan, Surabaya City, East Java \\ 60231, Indonesia \\ ${ }^{2}$ National Taiwan University of Science and Technology, No. 43 號, Section 4, Keelung Rd, Da'an \\ District, Taipei City, Taiwan 106
}

$\bowtie:{ }^{a)}$ abib.18089@mhs.unesa.ac.id, b)husnimubarok254@gmail.com, ${ }^{c}{ }^{c}$ binarprahani@unesa.ac.id

\begin{abstract}
This research was conducted to obtain a guided discovery learning implementation profile with virtual lab assistance and problem-solving skills for high school students on gas kinetic theory. The type of research was descriptive preliminary research, without hypothesis testing. The research subjects consisted of 106 students in senior high school. This study used qualitative descriptive analysis from questionnaires and online tests. This study revealed that the level of students' problem-solving skills was low. This case was proven by 102 students ( 27 male; 75 female) in the low category with a score range of 0 to 45 , and four students in the moderate category with a score range of 46 to 75 , while there were no students in the high category with a score range of 76 to 100 . This research implies that there is a need for a guided discovery learning model with the help of a virtual lab to analyze the problem-solving skills of high school students, especially on gas kinetic theory.
\end{abstract}

Keywords: guided discovery learning, PhET, problem-solving skills

\section{INTRODUCTION}

Education is an intentional effort to create a learning atmosphere and process when students can actively develop their latent capacities. For this situation, the targets for improving learning include attitudes, knowledge, and skills (Astra \& Wahidah 2017). National education is a conscious and planned effort to create a learning atmosphere and learning process. Students actively develop their potential to have religious-spiritual strength, self-control, personality, intelligence, noble character, and skills needed by society, nation, and nation-state (Puwanto \& Wahyuni 2018). School tends to be considered vital because it can grow every child's ability. So it is essential to choose a teaching framework that can create a pleasant atmosphere so that students' potential can develop well.

A teacher has a significant role in benchmarking and the learning process in general. But the delivery of material often still uses the old strategy. Where achievement is only assessed from learning outcomes, good learning must cover various cognitive, affective, and psychomotor aspects. It can be known well in terms of quality and quantity (Alatas et al. 2019). The learning process in schools that still apply conventional models includes peer tutors and lectures where the consequences of the learning model are not ideal. In addition, the absence of interactive media affects students' learning abilities which are still low. 
The learning model is a way that educators can carry out an active learning process. The appropriate learning model is a determinant of student success in understanding each material provided by the educator. In choosing a learning model, educators play an essential role in shaping the views and understanding of students later (Kariani, Ali \& Saehana 2018). In this way, when carrying out the learning and teaching process, educators can apply suitable and attractive learning models to effectively involve students, especially students' ability to deal with problems. Guided Discovery Learning is a learning model that gives students the freedom to compose, process, organize the data provided by the teacher based on understanding the right idea to solve an existing physics problem. Through the Guided Discovery process, students are required to utilize the thoughts and understanding they currently have to find something or new knowledge. Thus, learning with Guided Discovery is expected to help students' problem-solving abilities (Sutrisno 2012).

Discovery or problem-solving in physics assisted by a virtual lab will clarify abstract and complex to understand phenomena or events into something straightforward. The guided discovery learning model assisted by a virtual lab is appropriate for improving students' problem-solving abilities in the classroom, where students play an active role in various learning activities (Meisaroh, Achmadi \& Prahani 2020). However, the limited practical equipment in schools on certain materials is on the Gas Kinetic Theory, which makes students think that physics is a taboo subject. So that what needs to be strived for is that experimental activities can be carried out, namely making innovations that can support learning activities. One of the learning innovations that can be used for practical activities is PhET simulation. PhET (Physics Education Technology) is free software from the University of Colorado. Virtual lab applications that can be used other than PhET are PVL (Physics Virtual Lab), Vrealab, CoLearn, Physics Studio, Physics Lab, etc. However, the PhET application is often used because it is easier for students to use. Simulations in PhET are interactive and packaged interactively in a game-like structure so that students can explore them (Hidayat et al. 2019). Another advantage of this simulation can be run online or downloaded for free to be used offline. Inn ovative learning models in learning will affect the delivery of material. Less innovative learning models and media can make students less interested in learning. With the help of a virtual lab, the guided discovery learning model plays an essential role in improving students' problem-solving abilities. A virtual lab that utilizes the PhET application in delivering material will make it easier for students to solve problems and understand the concept of the gas kinetic theory.

To determine the level of students' problem-solving skills at Puncu senior high school, researchers used the NTEO and Taxonomy of Introductory Physics Problems (TIPP). They used the GW- ACCES strategy instructional protocol (Teodorescu, Bennhold, Feldman \& Medsker 2013). The steps for solving the ACCES problem consist of:

- A - Assen the problem

(Identify the problem principles needed to solve the problem)

- $\quad$ C-Create a drawing

(Translating words-in the form of pictures or pictures that contain instructions in solving problems)

- $\quad \mathrm{C}$ - Conceptualize the strategy

(Outlines the steps to be used in troubleshooting)

- $\quad$ E- Execute the solution

(Apply formulas to solve problems)

- $\quad$ S-Scrutinize your result (Are you sure)

- Sure - Not sure

In the first stage, students identify the principles of physics associated with the problem to know how the problem can be solved. In the next step, students present the problem in pictures to solve the problem. In the third stage, students describe the method used to deal with the problem so that they can quickly deal with the problem systematically. In the fourth stage, students apply the formula to solve the problem to get the correct result by following the principles and equations involved in dealing with the situation. In the fifth stage, students record the confidence level in the appropriate response between sure and not sure, along with the theory that underlies the written response (Fitriyani et al. 2019). 
Problem-solving is often a challenge for students because they do not understand the problemsolving process (Yu, Fan, \& Lin 2015). The researcher conducted this research because many high school students are still less skilled in solving physics problems. Students have difficulty solving physics problems, whereas previous students have been given material about concepts related to these problems by the teacher. The low skills possessed by students are influenced by several aspects, including learning in the classroom still using conventional learning models so that students are less enthusiastic in studying physics. Therefore, it is necessary to change the traditional learning model with the guided discovery learning model so that students become more active in the classroom. Of course, this learning requires media to support student learning, one of which is by utilizing the virtual lab media, likes PhET (Hidayat et al. 2019).

This study applies a guided discovery learning model assisted by a virtual lab. This study aims to analyze the physics problem-solving ability of students after using the guided discovery learning model assisted by PhET media on the material for the gas kinetic theory. The results of this study are expected to influence the learning model that has been applied to increase students' problem-solving skills.

\section{METHODS}

The preliminary research was used in this study. Primary research is the initial stage in conducting research and model development. Researchers make observations and collect data related to the application of the learning model to be carried out. The sampling technique in this study was purposive sampling. Researchers will consider the results of this study to develop learning methods that can improve students' problem-solving abilities. The research was conducted at Puncu senior high school with 106 students in 11th grade, consisting of three classes (Science 1, Science $2 \&$ Science 3). The data analysis technique uses student response questionnaires and online test questions (google form).

Student response questionnaires are used to describe the conditions and learning outcomes that students have carried out, teacher performance, the conditions and utilization of existing facilities and infrastructure, and whether the teacher introduces students to the PhET virtual lab application. Meanwhile, online test questions in the form of questions are used to explore data about students' problem-solving abilities. The instrument used is a description of the work carried out on the answer sheet listed the problem-solving skills assessment criteria (ACCES) (Teodorescu, Bennhold, Feldman $\&$ Medsker 2013). The data analysis technique used in this research is descriptive qualitative analysis. The analysis is used because the researcher wants to describe the facts and situations. 


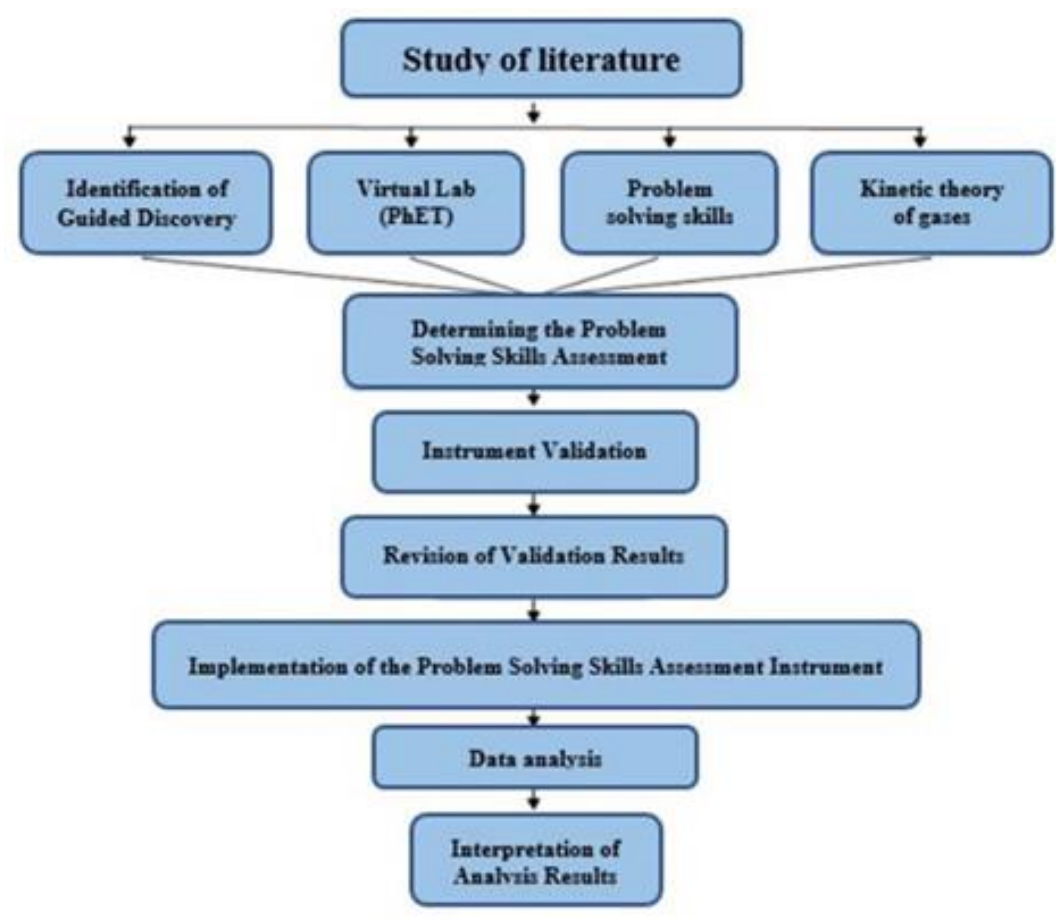

FIGURE 1. Research steps

\section{RESULTS AND DISCUSSION}

The results of this study are expected to determine physics problem-solving skills, especially in the material of the gas kinetic theory. This study aims to assess physics problem-solving skills, especially in the gas kinetic theory material. The student question link consists of 10 questions that require an explanation of the answers. The answer sheet provided is equipped with an indicator of problemsolving skills (ACCES). Students are asked to enter answers by following the arrows provided and then sent via a google form. Likewise, students were given a questionnaire consisting of 10 questions about students' experiences while studying Physics at school and questions about problem-solving skills, scientific experiments, and virtual laboratories.

\section{Test Results Validity and Reliability of Test Questions}

A question is said to be valid if the questions used can meet the aspects of validity and reliability. According to (Arikunto 1998), validity is a standard measure that shows an instrument's accuracy and validity. The validity or validity of an instrument is determined from the high and low validity values. Validity is also referred to as an aspect of measurement accuracy. A valid measuring instrument is not only able to produce precise data but also must provide a detailed description of the data. While the notion of reliability, according to (Sugiyono 2005) is a series of measurements or a series of measuring instruments that have consistency when the measurements made with the measuring instrument are carried out repeatedly. So test reliability is the level of consistency of a test, namely the extent to which an instrument can trust a test to produce a stable score, relatively unchanged even though it is tested in different situations. The following are the results of the validity test carried out using the IBM SPSS Statistics 25 application

TABLE 1. Validity Test Results

\begin{tabular}{cccc}
\hline QUESTION TO - & R $_{\text {TABLE }}$ & RCOUNT & DESCRIPTION \\
\hline 1 & 0.575 & VALID \\
2 & 0.437 & VALID \\
3 & 0.608 & VALID
\end{tabular}




\begin{tabular}{cccc}
\hline QUESTION TO - & R $_{\text {TABLE }}$ & RCOUNT & DESCRIPTION \\
\hline 4 & & 0.660 & VALID \\
5 & & 0.639 & VALID \\
6 & 0.195 & 0.643 & VALID \\
7 & & 0.438 & VALID \\
8 & & 0.519 & VALID \\
9 & 0.456 & VALID \\
10 & 0.581 & VALID \\
\hline
\end{tabular}

As seen in the results of the validity test table above, the basis for decision-making is valid if $r_{\text {count }}$ $>\mathrm{r}_{\text {table. }}$. Questions 1 to 10 have a validity value of 0.575 , respectively; $0.437 ; 0.608 ; 0.660 ; 0.639$; $0.643 ; 0.438 ; 0.519 ; 0.456 ; 0.581$. This result is greater than the value of $\mathrm{N}$, which is 0.195 . The value of $\mathrm{N}$ is obtained based on the provisions of the table $r_{\text {table. }}$. So that $r_{\text {count }}>r_{\text {table, }}$, then all questions are declared valid. Meanwhile, the following are the reliability tests carried out using the IBM SPSS Statistics 25 application.

TABLE 2. Reliability Test Results

\begin{tabular}{ccc}
\hline R $_{\text {TABLE }}$ & R $_{\text {COUNT }}$ & DESCRIPTION \\
\hline 0.195 & 0.736 & consistent/reliable \\
\hline
\end{tabular}

It can be seen in the results of the reliability test table above that the basis for decision making is said to be consistent if $r_{\text {count }}>r_{\text {table }}$ and the reliability value using SPSS is $0.736 . \mathrm{N}$ is 0.195 . The value of $\mathrm{N}$ is obtained based on the provisions of the table $\mathrm{r}_{\text {table. }}$. Then $0.736>0.195$ so that $\mathrm{r}_{\text {count }}>\mathrm{rt}_{\text {able }}$ then all questions are declared consistent/reliable.

Student Problem-solving Test Results

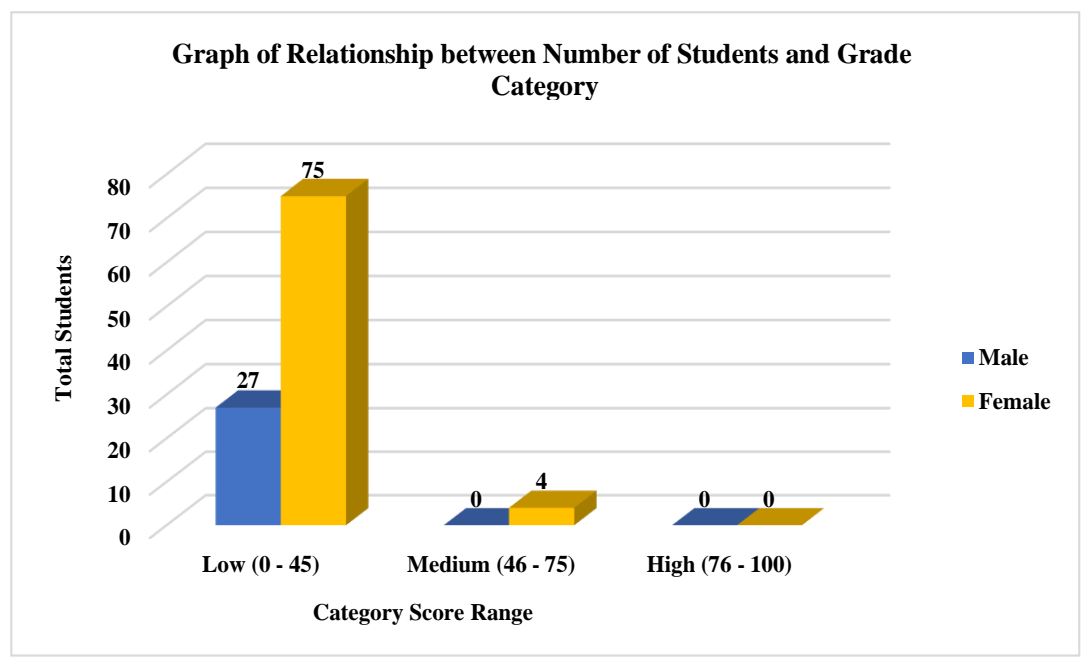

FIGURE 2. Graph of the relationship between the number of students and grade categories

Analyzing the results of student answers to test questions is the first step to finding causes and solutions for students who have difficulty solving problem-solving skills test questions. The test questions are equipped with ACCESS problem-solving skills indicators. Then, the score for one question is 10, divided into five ACCES problem-solving indicators, namely two for each indicator, so that the maximum score of 10 questions is 100 . Figure 1 above shows that students' problem-solving skills are included in the low category with a score of 0 to 45 , namely as many as 102 students, where 27 students are male and 75 students are female. And students who fall into the medium category with a score range of 46 to 75 are four female students, while there are no students in the high category with a score of 76 to 100 . 
The following is an example of student answers based on problem-solving skills indicators (ACCES) :

- $\quad$ A - Assen the problem

(Identify the problem principles needed to solve the problem)

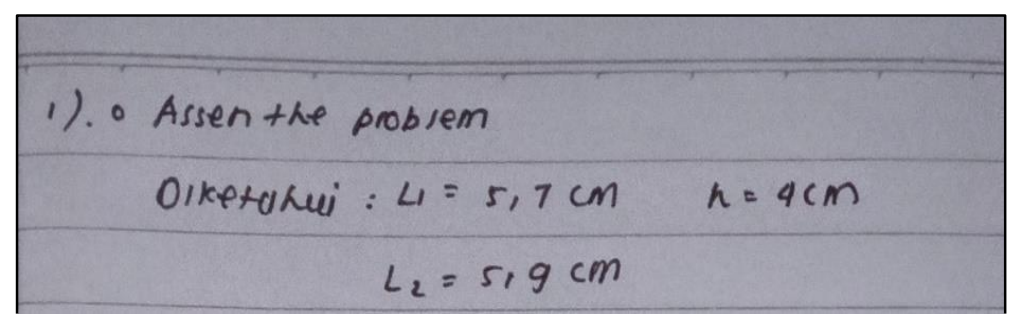

FIGURE 3. A-Assen the problem

FIGURE 3 above shows that students have not been able to identify the questions, the answers are given are still not quite right. Because the correct answer should be in the first condition, the tube containing the mercury is facing up, in the second condition, the tube is facing down. With a different

Length of the air column in the second state, it can be determined by Boyle's Law, the outside air pressure Po.

- C-Create a drawing

(Translating words-in the form of pictures or pictures that contain instructions in solving problems).

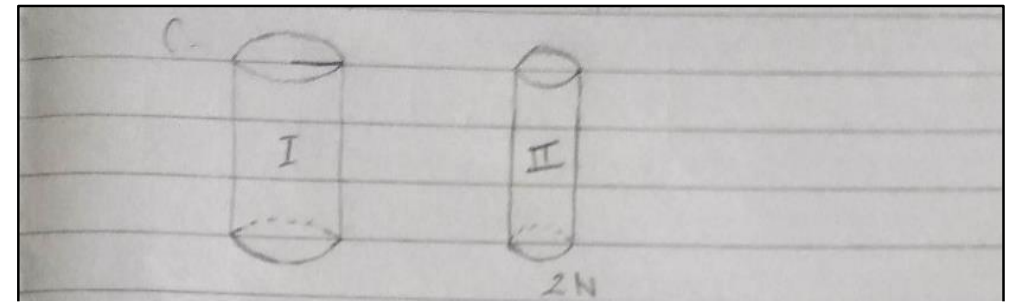

FIGURE 4. C-Create a drawing

FIGURE 4 above shows that students can translate the questions into pictures, but the description is still too small and has not been presented in detail.

- C-Conceptualize the strategy

(Outlines the steps to be used in troubleshooting).

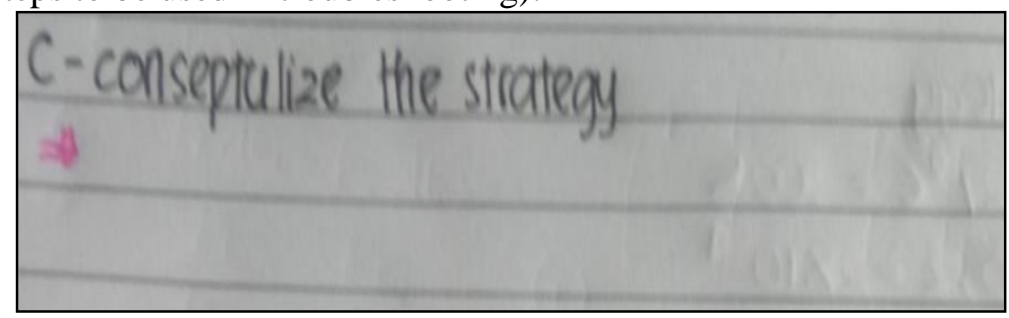

FIGURE 5. C-Conceptualize the strategy

FIGURE 5 above shows that students have not been able to describe the steps that will be used to solve a problem/problem.

- $\quad$ E - Execute the solution (Apply formulas to solve problems)

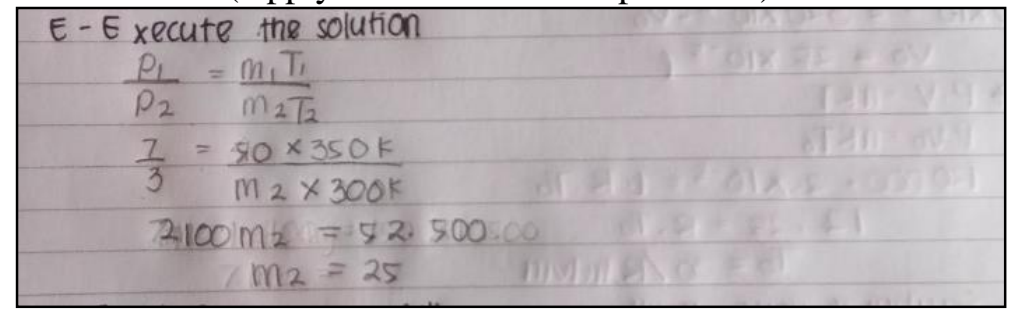

FIGURE 6. E-Execute the solution 
FIGURE 6 above shows that students can write the appropriate formula used to solve the problem, but the answer from the calculation is still not quite right.

- S-Scrutinize your result (Are you sure)

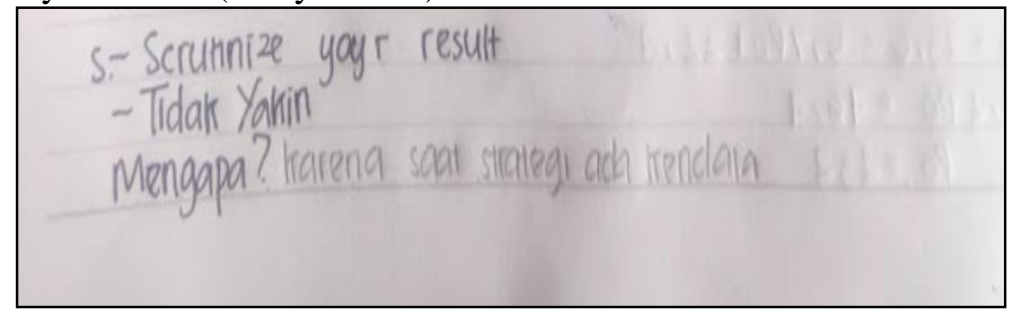

FIGURE 7. S-Scrutinize your result

FIGURE 7 above shows that students answered they were not sure with the reasons because they had problems / still did not understand.

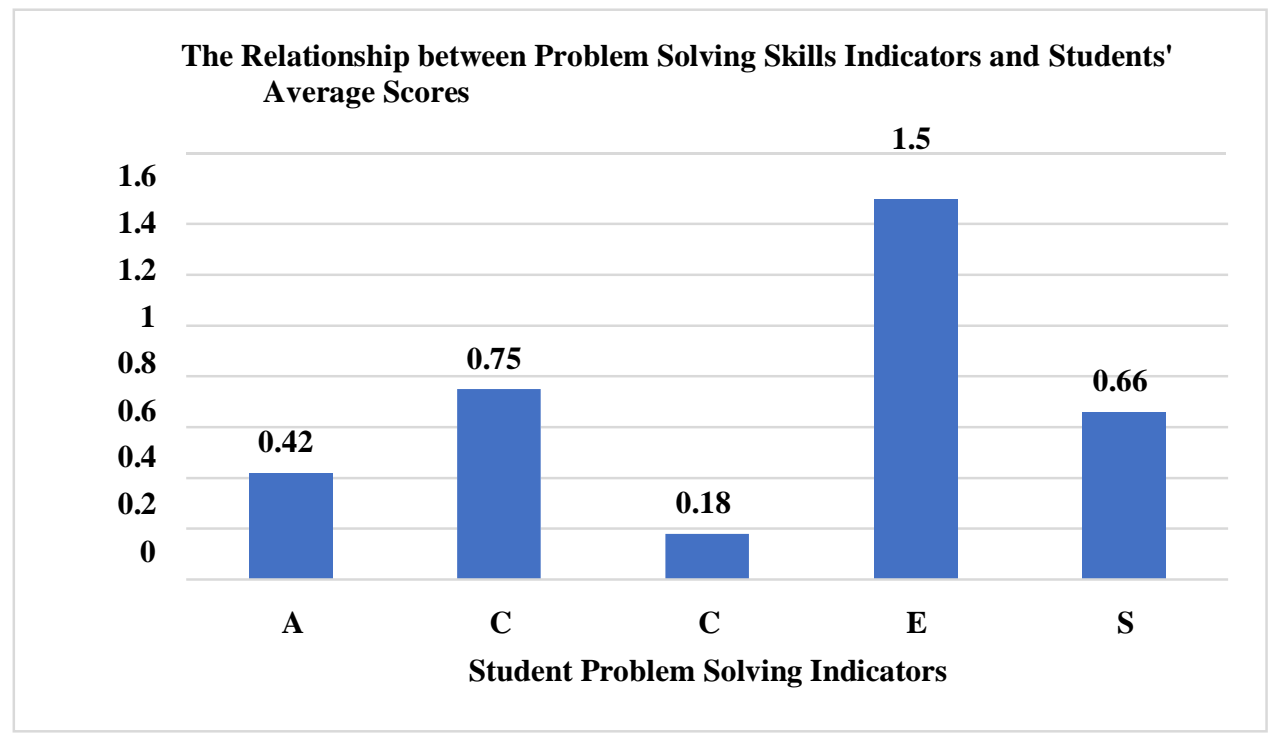

FIGURE 8. Graph of relationship between problem-solving skills indicators and students' average scores

In the graphic above, we can see that students cannot describe techniques well to solve problems with the lowest score on the problem-solving skill indicator C (conceptualizing strategies). This is because students have a misinterpretation indicated by the value obtained by students in problemsolving skills A (Assessing the problem). Students do not understand the concepts related to the problems that have been described. Sometimes some students only know the idea of the problem but do not fully understand. In problem-solving skills C (Making pictures) and E (implementing the solution), the average score of students is superior to the other three problem-solving skills. Students can make pictures containing instructions for working on problems, such as drawing sketches of tubes and vessels. While in problem-solving skills $\mathrm{S}$ (observing the results), students did not explain why they chose the "sure" answer on the answer sheet. Most students choose to believe but cannot explain the theory/concept that supports their answers, which shows that they need confidence. The low problem-solving skills are caused because students do not play an active role in learning, which is still focused on the teacher. This follows the assessment (Sahyar and Fitri 2017), which says that students are less selective in solving problems because learning is focused on educators. Students can do group learning to practice students' problem-solving skills (Hamdayama 2016). Students can also create Whatsapp groups to discuss online with friends and teachers. In addition, the application can be used even though the internet network is slow and the costs required are also relatively cheap (Farhan et al. 2021). 


\section{Student Response Questionnaire}

Based on the results of student interviews through a questionnaire via a google form. Which has been linked to the WhatsApp group, as many as 106 students of Puncu senior high school were asked to fill out a questionnaire related to problem-solving skills, consisting of 10 questions asked in a questionnaire with information :

$$
\begin{aligned}
& 1=\text { disagree }, \\
& 2=\text { disagree }, \\
& 3=\text { agree }, \text { and } \\
& 4=\text { strongly agree }
\end{aligned}
$$

\begin{tabular}{|c|c|c|c|c|c|}
\hline \multirow[t]{2}{*}{ No. } & \multirow[t]{2}{*}{ Statement } & \multicolumn{4}{|c|}{ Percentage $(\%)$} \\
\hline & & 1 & 2 & 3 & 4 \\
\hline 1 & Physics is the most difficult subject. & 1.8 & 25.7 & 56.9 & 15.6 \\
\hline 2 & I still study Physics even though I have no assignments/exams. & 3.2 & 52.3 & 43.1 & 1.4 \\
\hline 3 & $\begin{array}{l}\text { I have been trained with ACCES-based problem-solving test } \\
\text { questions soal. }\end{array}$ & 33 & 26.6 & 38.5 & 1.9 \\
\hline 4 & $\begin{array}{l}\text { I try to ask the teacher when I have trouble solving problems on the } \\
\text { questions. }\end{array}$ & 5.5 & 22 & 56.9 & 15.6 \\
\hline 5 & I'm having trouble doing the problem-solving ability test questions. & 0 & 20.2 & 60.6 & 19.3 \\
\hline 6 & I am always active when learning Physics online and offline. & 0.9 & 21.1 & 58.7 & 19.3 \\
\hline 7 & $\begin{array}{l}\text { The material "Gas Kinetic Theory" is very important to learn } \\
\text { because it relates to everyday life. }\end{array}$ & 1 & 11 & 59.6 & 28.4 \\
\hline 8 & $\begin{array}{l}\text { I prefer the lecture method compared to experimental-based } \\
\text { learning in the laboratory in learning Physics. }\end{array}$ & 19.3 & 52.3 & 23.9 & 4.5 \\
\hline 9 & $\begin{array}{l}\text { The implementation of the practicum can facilitate students' } \\
\text { understanding, especially in Physics lessons. }\end{array}$ & 1.8 & 1.8 & 56 & 40.4 \\
\hline 10 & $\begin{array}{l}\text { I will be interested if I use the PhET application in learning } \\
\text { Physics. }\end{array}$ & 5.5 & 33 & 56 & 5.5 \\
\hline
\end{tabular}

So the results are presented in TABLE 3 below :

TABLE 3. Student Response Questionnaire Results

From the table above, it can be concluded that students consider Physics to be the most challenging subject. This student's lack of interest is because most students disagree if they continue to study Physics even though there are no assignments/exams. Here students have been trained on ACCESbased problem-solving tests. Students also try to ask the teacher when they have difficulty working on the questions. However, students still find it challenging to work on problem-solving test questions, even though they are always actively participating in online/offline Physics learning. Most students agree that the material "Gas Kinetic Theory" is vital because it relates to everyday life. Students prefer experimental-based knowledge in the laboratory in physics compared to the lecture method. Therefore, students assume that implementing the practicum can facilitate understanding, especially in Physics lessons, then they will be more interested in using the PhET application in learning Physics. Students who only do virtual labs perform better than students who do both labs, regardless of the order. However, the findings from this analysis also suggest that when using both labs, having students do the physical lab before the virtual lab may be more beneficial for high school students than having them participate in the opposite order (Gnesdilow \& Puntambekar 2021). 


\section{Relevant Research Results}

Many studies have been conducted regarding the use of the Guided Discovery learning model by measuring problem-solving skills and other abilities, especially in physics. The results of previous studies relevant to using the Guided Discovery learning model are as follows in TABLE 4:

TABLE 4. Relevant Research Results

\begin{tabular}{|c|c|c|}
\hline AUTHOR (YEAR) & RESEARCH TITLE & FINDING \\
\hline Puwanto et al. (2018) & $\begin{array}{l}\text { The Problem-solving Ability of } \\
\text { SMAN 6 Kita Bengkulu } \\
\text { Students with the Application of } \\
\text { Animated Media-Assisted } \\
\text { Discovery Learning Model }\end{array}$ & $\begin{array}{l}>\text { This study aims to examine the effect of the } \\
\text { discovery learning model with the aid of } \\
\text { animation media at SMAN 6 Bengkulu City } \\
>\quad \text { This type of research is Quasi Experiment } \\
\text { Data collection techniques using students } \\
\text { problem-solving ability tests. } \\
\text { Data analysis using descriptive and inferential } \\
\text { analysis. } \\
\text { The results of the study can be concluded that } \\
\text { there is an effect of applying the discovery } \\
\text { learning model with the help of animation media } \\
\text { on the problem-solving abilities of } \\
\text { students at SMAN 6 Bengkulu City. }\end{array}$ \\
\hline Ramadan et al. (2020) & $\begin{array}{l}\text { Physics Online Learning } \\
\text { Devices Based on Guided } \\
\text { Discovery Model for High } \\
\text { School Class X on Momentum } \\
\text { and Impulse Material }\end{array}$ & $\begin{array}{l}\text { This development research aims to develop an } \\
\text { online Physics learning tool based on a guided } \\
\text { discovery model for class X high school students } \\
\text { with momentum and impulse materials and to } \\
\text { test the feasibility of online Physics learning } \\
\text { tools through validator assessment (material } \\
\text { experts) and limited trials by students. } \\
\text { This type of research is research and } \\
\text { development research (R\&D). } \\
\text { The method of data collection in research using } \\
\text { a questionnaire } \\
\text { The results of this study can be concluded that } \\
\text { online physics learning tools based on guided } \\
\text { discovery learning models can be used in } \\
\text { online learning on momentum and impulse } \\
\text { materials. }\end{array}$ \\
\hline
\end{tabular}

Alatas et al. (2019) Guided discovery assisted by virtual labs to improve science process skills and scientific behavior
Improving Students' Science Process Skills Through Guided Discovery Learning Model Class XI MIPA on Temperature and Heat Materials
$>$ This study aims to improve science process skills and scientific attitudes based on students' IQ on the concept of simple harmonic motion through a guided discovery learning model assisted by a virtual lab on simple harmonic motion material.

$>$ Quasi-experimental method with nonequivalent control group design

$>$ Data collection techniques in this study using test and non-test techniques teknik

$>$ The results of this study can be concluded that the guided discovery model assisted by virtual labs can improve students' science process skills in the entire IQ group.

$>$ This study aims to find out how much the increase in students' science process skills after the guided discovery learning model was applied to the temperature and heat material

$>$ The research design used is Classroom Action Research (CAR) which consists of three cycles

$>$ The research instrument used is the observation sheet of science process skills and the assessment of student worksheets

$>$ The results of the study, it can be concluded that there is an increase in students' science process 


\begin{tabular}{cc}
\hline AUTHOR (YEAR) & RESEARCH TITLE \\
\hline & \\
& \\
Kariani et al. (2018) & $\begin{array}{l}\text { The Effect of Guided Discovery } \\
\text { Learning Model on Physics } \\
\text { Learning Outcomes in Class VII } \\
\text { Students of SMP Negeri 9 Palu }\end{array}$
\end{tabular}

Cindikia et al. (2020)

Sayyadi et al. (2016)

Maharani et al. (2019)

Prahani et al. (2021)
Profile of Students' Problemsolving Skills and the Implementation of Assisted Guided Inquiry Model in Senior High School

The Influence of Guided Inquiry Learning Strategies and on the Ability to Solve Physics Problems on the Material of Temperature and Heat Judging from the Initial Ability of Students

The Use of Google Classroom as a Virtual Classroom Development in ProblemSolving Skills in Kinematics Topics in Computer Systems Department Students

Profile of Students' Physics Problem-Solving Skilla and the Implementation of Inqury (Free, Guided, Structured) Learning in Senior High School

\section{FINDING}

skills after the guided discovery learning model is applied to the material of

$>$ temperature and heat.

$>$ The purpose of the study was to determine the effect of the guided discovery learning model on physics learning outcomes in class VII students of SMP Negeri 9 Palu

$>$ This type of research is a quasi-experimental design with a randomized pretest-posttest control group.

$>$ The design used in this study is a "randomized pretest-posttest control group design"

$>$ The results of this study can be concluded that there is an effect of guided discovery learning model on physics learning outcomes in Class VII students of SMP Negeri 9 Palu.

$>$ The purpose of this study is to analyze the profile of students' problem-solving skills and the application of guided inquiry in high school.

$>$ The type of research used is preliminary research methods with data collection techniques in the form of tests and questionnaires.

$>$ Descriptive qualitative data analysis techniques.

$>$ The results of this study indicate that only a few students can work on the material using problemsolving strategies strategi

$>$ This study aims to determine the effect of guided inquiry learning strategies on the ability to solve physics problems on the material of temperature and heat seen from the students' initial abilities

$>$ This research is a quasi-experimental research

$>$ The data obtained were analyzed using a twoway analysis of variance, the influence of learning was tested by the Tukey test

$>$ The results of the analysis show that there is an influence of students' initial abilities on problemsolving abilities and physics problem-solving abilities in the experimental class better than the control class.

$>$ The purpose of this research is to develop student problem-solving skills in the topic of parabolic motion and to test the effectiveness of Google Classroom in the learning process on parabolic motion material.

$>$ The research method used is development research based on qualitative description

$>$ The research was conducted with pre-research, experimental, written test evaluation and questionnaire stages

$>$ Data were analyzed descriptively qualitatively supported by quantitative data

$>$ The results show that the use of Google Classroom runs optimally

$>$ The research objective is to determine the profile of students' physics problem-solving skills.

$>$ This type of research uses Descriptive Research Design (DRD).

$>$ Data collection methods using tests, questionnaires, and interviews. 


\begin{tabular}{cl}
\hline AUTHOR (YEAR) & \multicolumn{1}{c}{ RESEARCH TITLE } \\
\hline Hidayat et al. (2019) & $\begin{array}{l}\text { The Effect of Guided Discovery } \\
\text { Learning Model Aided by PhET } \\
\text { Simulation Media on Students' } \\
\text { Understanding of Physics } \\
\text { Concepts }\end{array}$ \\
\end{tabular}

Simamora et al. (2019)

Improving

Mathematical Problem- sol Ability and Self Efficacy through Guided Discovery Learning in Local Culture Context

Profile of Students' ProblemSolving Skills and the Implementation of Free Inquiry Model in Senior High School

Kalatting et al. (2015)
Development of Web- based Physics Learning Media using Guided Discovery Learning Approach

\section{FINDING}

The results show that only a few students can work on the material using the ACCES problemsolving indicator.

$>$ The purpose of this study is to analyze the effect of guided discovery learning model assisted by PhET simulation media on students' understanding of physics concepts.

$>$ This research uses quasi-experimental research.

$>$ The research design used is the matching only posttest control group design.

$>$ Data collection using a concept understanding test instrument.

$>$ The results of this study show that the guided discovery learning model has a significant effect on students' understanding of physics concepts.

$>$ The purpose of this research is to improve students' mathematical problem-solving ability and mathematical self-efficacy.

$>$ This research is a development research (design research).

$>$ This research model is the development of Thiagarajan.

$>$ The result of this research is that students' mathematical problem-solving abilities and selfefficacy who are studied using the GDL- BTCC final material increase compared to classes taught using ordinary learning.

$>$ This study aims to determine the profile of students' problem-solving skills and the application of the free inquiry model in high school.

$>$ This type of research is carried out using preliminary research methods with data collection techniques in the form of written tests.

$>$ Data collection techniques used were analyzed descriptively qualitatively.

$>$ The results of the study can be concluded that the application of the free inquiry learning model assisted by virtual laboratories (PhET) in schools does not optimally cause students to become inactive in class so that students' problemsolving skills are not yet in the high category.

$>$ The purpose of this research is to improve and support physics learning and can help students understand the substance of Physics in the 2013 Curriculum

$>$ Types of research data in the form of comparative descriptive data

$>$ The research method used is development research with the Borg and Gall model (1983), educational research and development is a process used to develop and validate educational products

$>$ The results of this research are web-based learning media with Guided Discovery Learning approach is needed to facilitate and assist students in learning physics, physics teachers throughout Jakarta also welcome this web-based media 


\begin{tabular}{|c|c|c|}
\hline AUTHOR (YEAR) & RESEARCH TITLE & FINDING \\
\hline Devanti, et al. (2020) & $\begin{array}{l}\text { Profile of Student' Problem- } \\
\text { solving Skills and the } \\
\text { Implementation of Structured } \\
\text { Inqury Model in Senior High } \\
\text { Schools }\end{array}$ & $\begin{array}{l}\text { The purpose of the research is to find out } \\
\text { students' problem-solving skills } \\
\text { The type of research used is preliminary research } \\
\text { Data collection techniques using tests, } \\
\text { questionnaires and interviews } \\
\text { Descriptive qualitative data analysis techniques } \\
\text { Research results can be concluded if students' } \\
\text { problem-solving skills are still low }\end{array}$ \\
\hline Sutarno et al. (2017) & $\begin{array}{l}\text { Student Problem-solving Skills } \\
\text { in Physical Pendulum Learning } \\
\text { using the Problem-solving } \\
\text { Virtual Laboratories Model }\end{array}$ & $\begin{array}{l}>\quad \begin{array}{l}\text { Research objectives to explore problem- } \\
\text { solving skills }\end{array} \\
>\quad \begin{array}{l}\text { Type of quasi-experimental research with non- } \\
\text { equivalent control group design }\end{array} \\
>\quad \begin{array}{l}\text { Subjects } 70 \text { students were divided into control } \\
\text { and experimental groups }\end{array} \\
>\quad \begin{array}{l}\text { The results of the study showed that the } \\
\text { improvement of the problem-solving skills of the } \\
\text { experimental group students and the control } \\
\text { group was significantly different. }\end{array}\end{array}$ \\
\hline
\end{tabular}

Based on TABLE 4 above, we can conclude that the learning model can influence students' problem-solving abilities. Learning media assisted by virtual lab applications can help students better understand the material. Utilization of learning methods using guided discovery with virtual labs is needed to help students improve skills in dealing with a problem (Sutarno et al. 2017). The use of media-assisted guided discovery learning models on students' problem-solving abilities is very influential (Puwanto et al. 2018). Based on the description above, the types of research that have been carried out previously, with the result that the learning process using guided discovery learning is proven to be effective for students who have never used the inquiry learning model before. The application of $\mathrm{PhET}$ for subjects that cannot be done in the practicum will help students better understand the related material. For example, in the matter of the gas kinetic theory. This has been tested with various kinds of tests that have been carried out, both tests on students and tests or validation of learning tools used. By using the guided discovery learning model assisted by PhET, it is hoped that students can solve problems better than before.

\section{CONCLUSION}

Based on the data and discussion above, it can be concluded that students' problem-solving skills at Puncu senior high school were low. Based on the student response survey results and the completed ACCES indicator problem-solving skills test, the problem-solving skills need to be trained by educators, especially in physics subjects on gas kinetic theory. In research, students have never been invited to practicums, especially on the gas kinetic theory. The laboratory at school was not adequate, and students have never been familiar with virtual laboratories, one of which is PhET. Virtual lab applications other than PhET are PVL (Physics Virtual Lab), Vrealab, CoLearn, Physics Studio, Physics Lab, and so on. However, the PhET application is often used because it was designed as attractive as possible. The settings in this simulation are simple and easy to use by students. Another advantage of this simulation can be run online or downloaded for free to be used offline. Efforts that can be made to improve problem-solving skills are to apply guided discovery learning models with the help of a virtual lab. Efforts meant giving students the freedom to compile, process, and organize data provided by the teacher based on understanding the right idea. By using their knowledge, skills, and understanding, students can solve a problem. So that students can solve problems well based on the ACCES indicator. Therefore, problem-solving skills are needed that require a learning model that has never been taught, namely by utilizing the guided discovery learning model assisted by the virtual lab. 


\section{ACKNOWLEDGMENT}

Thanks to Lecturer in Universitas Negeri Surabaya, Physics Teacher and students of Puncu senior high school, and all parties who have provided a lot of assistance in supporting the completion of this research.

\section{REFERENCES}

Alatas, F \& Sakina, WH 2019, 'Guided discovery berbantuan virtual lab untuk meningkatkan keterampilan proses sains dan sikap ilmiah', JIPVA (Jurnal Pendidikan IPA Veteran), vol. 3, pp. $138-148$.

Astra, IM \& Wahidah, RS 2017, 'Peningkatan Keterampilan Proses Sains Peserta Didik Melalui Model Guided Discovery Learning Kelas XI MIPA pada Materi Suhu dan Kalor', Jurnal Penelitian \& Pengembangan Pendidikan Fisika, vol. 3, no. 2, pp. 181-190.

Cindikia, M, Achmadi, HR, Prahani, BK 2020, 'Profile of Student's, Problem-solving Skills and the Implementation of Assisted Guided Inquiry Model in Senior High School', Studies in Learning and Teaching (SiLET), vol. 1, no. 1, pp. 52-62.

Devanti Selonita Oldi, Hainur Rasyid Achmadi 2020, 'Profile of Students, Problem- solving Skills and the Implementation of Structured Inquiry Models in Senior High Schools Students, Problemsolving Skills and the Implementation of Structured Inquiry', Berkala Ilmiah Pendidikan Fisika, vol. 8, no 3, pp. 144-156.

Farhan, A, Herliana, F, Evendi, E, Devy, NK, \& Mauliza, F 2021, 'The Implementation of "Guru Penggerak" (Organizer Teachers) Concept to Innovation of The Discussion Methods in Thermodynamics Course', Jurnal Penelitian \& Pengembangan Pendidikan Fisika, vol. 7, no. 1, pp. $1-12$.

Fathiah, F, Kaniawati, I \& Utari, S 2015, 'Analisis didaktik pembelajaran yang dapat meningkatkan Singgah antara pemahaman konsep dan kemampuan masalah siswa SMA pada materi fluida dinamis', Jurnal Penelitian \& Pengembangan Pendidikan Fisika, vol. 1, no. 1, pp. 111-138.

Fitriyani, RV, Supeno, S \& Maryani, M 2019, 'Pengaruh LKS Kolaboratif Pada Model Pembelajaran Berbasis Masalah Terhadap Keterampilan Pemecahan Masalah Fisika Siswa SMA', Berkala Ilmiah Pendidikan Fisika, vol. 7, no. 2, pp. 71-81.

Gnesdilow, D \& Puntambekar, S 2021, 'Comparing Middle School Students' Science Explanations During Physical and Virtual Laboratories', J Sci Educ Technol.

Hidayat, R et al. 2019, 'Pengaruh Model Guided Discovery Learning Berbantuan Media Simulasi PhET Terhadap Pemahaman Konsep Fisika Siswa', Berkala Ilmiah Pendidikan Fisika, vol. 7, no. 2, pp. 97-104.

Kalatting, S, Serevina, V \& Astra, IM 2015, 'Pengembangan Media Pembelajaran Fisika Berbasis Web Menggunakan Pendekatan Guided Discovery Learning', Jurnal Penelitian \& Pengembangan Pendidikan Fisika, vol. 1, no. 1, pp. 1-8.

Kariani, K, Ali, M \& Saehana, S 2018, 'Pengaruh Model Pembelajaran Guided Discovery Terhadap Hasil Belajar Fisika Pada Siswa Kelas VII SMP Negeri 9 Palu’, vol. 6, no. 1, pp. 29-39.

Maharani, N \& Kartini, KS 2019, 'Penggunaan Google Classroom Sebagai Pengembangan Kelas Virtual Dalam Keterampilan Pemecahan Masalah Topik Kinematika pada Mahasiswa Jurusan Sistem Komputer', PENDIPA Journal of Science Education, vol. 3, no. 3, pp. 167-173.

Meisaroh, S, Achmadi, HR \& Prahani, BK 2020, 'Profile of Students' Problem-solving Skills and Implementation Free Inquiry Model in Senior High School', Berkala Ilmiah Pendidikan Fisika, vol. 8 , no. 2 , p. 59. 
Muhammad Sayyadi, Arif Hidayat, M 2016, 'Pengaruh Strategi Pembelajaran Inkuiri Terbimbing dan Terhadap Kemampuan Pemecahan Masalah Fisika Pada Materi Suhu Dan Kalor Dilihat Dari Kemampuan Awal Siswa', Jurnal Inspirasi Pendidikan Universitas Kanjuruhan Malang, pp. 866875.

Prahani, BK et al. 2021, 'Profile of Students' Physics Problem-Solving Skills and the Implementation of Inquiry (Free, Guided, and Structured) Learning in Senior High School', Journal of Physics: Conference Series, vol. 1747, no. 1.

Puwanto, A \& Wahyuni, S 2018, 'Kemampuan Pemecahan Masalah Siswa SMAN 6 Kita Bengkulu dengan Penerapan Model Pembelajaran Penemuan', Prosiding Seminar Nasional Fisika (EJournal), vol. 7, pp. 152-160.

Ramadan, EM \& Rahmawati, DU 2020, 'Physics Online Learning Devices Based on Guided Discovery Model for High School Class X on Momentum and Impulse Material', Jurnal Penelitian \& Pengembangan Pendidikan Fisika, vol. 6, no. 2, pp. 163-172.

Simamora, ER, Saragih, S, Hasratuddin 2019, 'Improving Students' Mathematical Problem Solving Ability and Self-Efficacy through Guided Discovery Learning in Local Culture Context', International Electronic Journal of Mathematics Education, vol. 14, no. 1. pp. 61-72.

Soderstrorm, T, Dari, J, Lovqvist, J \& Tornquist, A 2011, 'Dari jarak jauh ke pendidikan online: Manajemen pendidikan di abad ke-21', Konferensi Tahunan Dublin.

Sugiyono 2005, 'Metode Penelitian Kualitatif', Bandung: Alfabeta.

Sutarno, Agus Setiawan, Andi Suhandi, Ida Kaniawati, DHP 2017, 'Keterampilan Pemecahan Masalah Mahasiswa dalam Pembelajaran Bandul Fisis Menggunakan Model Problem-solving Virtual Laboratory', Jurnal Pendidikan Fisika dan Teknologi (ISSN. 2407-6902), vol. 3, no. 2, pp. 164-172.

Sutrisno, E 2012, 'Efektivitas Pembelajaran dengan Metode Penemuan Terbimbing terhadap Pemahaman Konsep Matematis Siswa', Jurnal pendidikan matematika, vol. 1, no. 4.

Teodorescu, R, Bennhold, C, Feldman, G \& Medsker, L 2013, 'Pendekatan baru untuk menganalisis masalah fisika: SEBUAH taksonomi dari masalah pengantar fisika', The American Physical Society.

Yu, KC, Fan, SC, \& Lin, KY 2015, 'Enhancing Students' Problem-Solving Skills Through ContextBased Learning', Int J of Sci and Math Educ, vol. 13, pp. 1377-1401.

Zainuddin, Z, Hasanah, AR, Salam, MA, Misbah, M \& Mahtari, S 2019, 'Mengembangkan multimedia interaktif dalam pembelajaran fisika', Jurnal Fisika: Seri Konferensi, pp. 1171. 